\title{
Project Culture in the Chinese Construction Industry: Perceptions of Contractors
}

Jian Zuo and George Zillante (School of Natural and Built Environments, University of South Australia, Australia)

Vaughan Coffey (School of Urban Development, Queensland University of Technology, Australia)

\section{ABSTRACT}

In recent years culture has become one of the most studied topics in project management research. Some studies have investigated the influence of culture at different levels - such as national culture, industry culture, organisational culture and professional culture. As a project-based industry, the construction industry needs to have more insight concerning cultural issues at the project level and their influence on the performance of construction projects. Few studies, however, have focused on culture at the project level. This paper uses a questionnaire survey to determine the perceptions of Chinese contractors about the impact of project culture on the performance of local construction projects. This is augmented by a series of in-depth interviews with senior executive managers in the industry. The findings indicate that specific project culture does contribute significantly towards project outcomes. In particular, goal orientation and flexibility, as two dimensions of project culture, have a negative statistical correlation with perceived satisfaction of the process, commercial success, future business opportunities, lessons learnt from the project, satisfaction with the relationships, and overall performance. This paper also indicates that the affordability of developing an appropriate project culture is a major concern for industry practitioners.

Keywords: project management, culture, project performance, affordability, construction industry, China.

\section{INTRODUCTION}

Many researchers and practitioners believe that culture is one of the main determinants of management practice. Some studies have investigated the influence of culture at different levels (e.g. national culture, organisational culture, industry culture and professional culture) on project management practice (Loosemore and MusImani, 1999; Chan and Tse, 2003; Rowlinson, 2001; McGeorge et al., 2002; Wang, 2001). However, few studies have focused on culture at the project level and its influence on construction project management practice. Given that the construction industry is project-based (Black et al., 2000; Sözen and Kayahan, 2001; Whyte et al., 2002), such issues need to be examined at the project level.

The main objectives of this paper are to:

- review the literature on project culture,

- $\quad$ investigate project culture in the Chinese construction industry and its impact on the performance of construction projects, and

- discuss the findings and provide suggestions on how to manage culture at the project level.

\section{PROJECT CULTURE}

\section{GENERAL CONCEPTS}

There are a few studies that discuss the concept of project culture and its impact on business operations. Generally, project culture is defined as the general attitude towards projects within the business (Widmen, 2004).

Korzilius (1988) stresses that it is very important to establish a unified, strong project culture for successful projects, as a lack of a unified culture can be detrimental to the attainment of the overall project objectives.

Project culture was identified by Gareis and Huemann (2000) as an objective of the project management process, together with the scope of work, the project schedule, the project costs, the project organisation and the project context. Furthermore, it is a project manager's ability to shape project culture that stimulates teamwork and high levels of personal motivation, as well as a capacity to quickly identify and resolve problems that threaten project work (Gray and Larson, 2000). Similarly, there are many claims in the literature about the importance of project culture (Kwan and Ofori, 2001; Walker, 2002) although these are rarely supported by empirical research.

\section{EMPIRICAL RESEARCH}

Most empirical studies on project culture are of a quantitative nature. Anderson (2003) applies the organisational culture model and instrument developed by Harrison (1972) and advanced by Handy (1985) to measure culture at both project and organisational levels. The outcome of a project was found to have a weak correlation with task-oriented culture, which is generally regarded as the appropriate project culture. The results show that a strong task-oriented culture may improve the budget performance of a project, while having no direct influence on other performance factors of a project such as schedule, participants' satisfaction and functionality of the final product.

Gray (2001) conducted a study to examine the relationship between project outcomes and the social and management climate in which those projects are implemented. Based on extensive field research involving project management professionals in major British organisations, there is evidence to suggest that project success declines as the level of personal and environmental threat perceived by project staff increases. Other organisational characteristics, such as free expression, questioning, participation in the definition of goals, innovation and intrinsic satisfaction from the work itself, are all found to be positively associated with successful project outcomes, while organisational change and conflict are negatively associated with project success.

Thomas et al. (2002) employed the standard 'Competing Values Framework' model as well as the instrument developed by Cameron and Quinn (1999) to assess the project culture of thirteen 
Australian construction projects. The findings indicated that clantype cultures were positively correlated with quality outcomes whereas market cultures, more common on construction projects, were found to be negatively correlated with quality outcomes.

Thomas et al. (2002) subsequently suggested that the project culture of construction projects should be shifted from the current common market culture to a clan culture. They argue that a project culture should be designed to align organisational goals and objectives with those of the individual participants (which helps to reduce conflicts), to enhance communication and coordination and to increase the ease with which project objectives are achieved.

Kumaraswamy et al. (2001) suggested a framework to explain and analyse the origins and formation of project culture in construction projects. In this framework, a typical project culture is derived from a set of four overlapping sub-cultures: i.e. organisational subcultures, operational sub-cultures, professional sub-cultures, and individualistic sub-cultures.

Project culture can also be evaluated via a qualitative approach. For example, van Marrewijk (2007) investigated the development of the project culture of the Environ Megaproject for the project life cycle using anthropological fieldwork methods to collect data. The culture of the Environ Megaproject was found to consist of innovativeness, creativeness, non-traditionalism, and independency.

\section{LIMITATIONS}

Previous studies about project culture have had several limitations including:

- No clearly accepted definition of project culture, especially in the context of construction projects, resulting in significant difficulties in conceptualising and measuring the project culture.

- The few examples of a simple application of a conventional organisational culture model to measure the project culture of construction projects (e.g. Thomas et al., 2002) are limited, as they are derived from generic management organisational culture models and pay little consideration to the specific characteristics of construction projects. For instance, the integration between the functional departments of one organisation, which is highlighted in numerous organisational culture models (e.g. Cameron and Quinn, 1988; Harrison, 1972; Handy, 1985) must be modified to suit construction projects (Kog et al., 1999; Arditi et al., 2002).

- The framework proposed by Kumaswamy et al. (2001; 2002 ) is too complex to measure project culture by applying Hofstede's (2001) cultural model to each sub-culture and its contributory components. Given the number of organisations and specialists involved in a typical construction project, it is not surprising that a lot of resources are required to diagnose the project culture.

In summary, measuring the project culture in one construction project requires a relatively simple, easy to use and contextspecific framework.

With reference to the well-recognised definition of organisational culture (Hofstede, 2001; Schein, 1985), Zuo and Zillante (2005) defined project culture as 'the shared values, basic assumptions and beliefs that the participants involved in a project hold that determine the way they process the project and the relationship with each other in the project environment'. Subsequently they proposed a conceptual framework (see Table 1) to measure the project culture in the construction context.

Table 1: The components of the proposed project culture model

\begin{tabular}{l}
\hline Integrative \\
\hline Inputs of various contributing parties (for example, design, \\
construction and consultants) are encouraged in the early stages of \\
the project process. \\
\hline Cooperative \\
\hline There are few conflicts during the process of the project. Emphasis \\
is placed on aligning the objectives of different participants and \\
organisations to a common goal - the objectives of the project. \\
Teamwork is popular. The project participants are collaborative with \\
each other. \\
Goal-oriented \\
Results are always given the highest priority while the means to \\
obtain the goals can be tolerated in the construction projects with a \\
goal-oriented culture. Risk-taking is acceptable to accomplish the \\
task in specific conditions and project participants are comfortable \\
with uncertainty within the project environment. \\
Flexible \\
The way a project is processed is very flexible and easy to change in \\
the projects with a flexible culture. Innovative approaches, which \\
include risk-taking, are encouraged and rewarded in the project \\
process. Failure is viewed as an opportunity for learning and \\
improvement. \\
\hline People-oriented \\
\hline The people issues are given higher priority in the construction \\
projects with a people- oriented culture. Decision-making is pushed \\
down. Opportunities are given to develop capabilities during the \\
project process.
\end{tabular}

\section{RESEARCH METHODOLOGY}

\section{DEVELOPMENT OF THE CONCEPTUAL FRAMEWORK AND ASSOCIATED RESEARCH INSTRUMENTS}

Zuo and Zillante's (2005) model is one of the very few studies that investigate project culture issues in the construction industry. During the development of the definition and conceptual framework of project culture, Zuo and Zillante (2005) adapted the well recognised organisational culture models of Hofstede (2001) and Cameron and Quinn (1999) whilst considering the special characteristics of construction projects. Accordingly this model was considered to be an appropriate model to use to measure the culture of construction projects.

Empirical research was conducted to test the validity of the Zuo and Zillante (2005) model. Initially, field studies were conducted. These comprised observational studies of project meetings and preliminary interviews with project participants in order to identify the features of project culture in construction projects. Interviewees were also asked to nominate key performance indicators for measuring the success of their projects.

The aim of attending the project meetings was: (1) to understand current practice in the Australian construction industry; and (2) to observe any manifestations of project culture during the meeting. The researchers simply observed the proceedings of the meeting (e.g. the common topics for the meeting, communication methods, negotiation methods and dispute resolution methods) without asking any questions.

Initially a letter was sent to major construction firms in South Australia requesting assistance in locating projects that the authors could use for the purpose of attending site meetings. The response was overwhelming in terms of numbers and the projects were selected at random. Ten projects facilitated by four different 
construction firms were selected for attendance. These four construction firms were the four largest in South Australia and thus the meetings provided good insights about the way that projects are managed in this State.

Preliminary interviews were then conducted with a separate group of interviewees, representing government agencies, construction firms, architects, engineering and project management consultants. A total of 21 respondents took part in the preliminary interviews. They comprised industry professionals who had been involved in a number of construction projects. Their roles included acting as the client, the main contractor, the architect, the quantity surveyor and the project manager. These practitioners were selected from the major companies that provide services and functions within the construction industry in South Australia. The reason for attending the site meetings and conducting the preliminary interviews was to collect statements that enabled the quantification of each dimension of the project culture model.

The outcome of this process was a questionnaire and interview schedule developed from the theoretical model and tested and modified following observations of project meetings and preliminary interviews with academic and industry experts. The questionnaire was also tested in pilot studies (Zuo and Zillante, 2006a).

\section{MEASUREMENT OF PROJECT PERFORMANCE}

Generally, cost, time and quality are recognised as the most important performance dimensions of construction projects (Xiao and Proverbs, 2002; Odusami et al., 2003; Baloi and Price, 2003). Some researchers suggest that safety should be added to that list (Cox et al., 2003; Lim and Mohamed, 1999; Sawacha et al., 1999). These performance indicators are employed to measure the performance of a project, the most important of which are viewed as key performance indicators (KPIs).

This study examined the performance of a construction project by utilising the perception of the project participants. The evaluation of project personnel, users and other stakeholders are identified as one of the ways of measuring the performance and success of a project (Diallo and Thuillier, 2004; Westerveld, 2003). It is not the intention of this study to determine the best indicators of project performance. Rather, a list of common performance indicators was adopted in order to measure the relationship between project culture and project performance. A list of common performance indicators was shown to the industry practitioners during the preliminary interviews. The measures of project performance adopted in this study are shown in Table 2.

Table 2: Dimensions and measures of project performance adopted in this study

\begin{tabular}{lll}
\hline $\begin{array}{l}\text { Performance } \\
\text { dimensions }\end{array}$ & Measures & References \\
\hline $\begin{array}{l}\text { Economic } \\
\text { aspect }\end{array}$ & $\begin{array}{l}\text { 1. Commercial success } \\
\text { 2. Future business } \\
\text { opportunities }\end{array}$ & $\begin{array}{l}\text { Chan and Chan (2004); } \\
\text { Bassioni et al. (2005); } \\
\text { Shenhar et al. (2001) }\end{array}$ \\
\hline $\begin{array}{l}\text { Continuous } \\
\text { improvement }\end{array}$ & $\begin{array}{l}\text { 3. Satisfaction with the } \\
\text { project process } \\
\text { 4. Lessons learnt from the } \\
\text { project }\end{array}$ & $\begin{array}{l}\text { Chan and Chan (2004); Luu } \\
\text { et al. (2008) }\end{array}$ \\
\hline $\begin{array}{l}\text { Relationship } \\
\text { aspect }\end{array}$ & $\begin{array}{l}\text { 5elatisfaction with the } \\
\text { relatip with other parties }\end{array}$ & $\begin{array}{l}\text { Chan and Chan (2004); } \\
\text { Bassioni et al. (2005); } \\
\text { Shenhar et al. 2001; Luu et } \\
\text { al. (2008); Wang and Huang } \\
\text { (2006) }\end{array}$ \\
\hline Overall & 6. Overall performance & Lam et al. (2007) \\
\hline
\end{tabular}

\section{QUESTIONNAIRE SURVEY AND INTERVIEWS}

The questionnaire was translated into Chinese for use in Mainland China. A similar approach to Low and Shi (2002) was adopted. The English version questionnaire was firstly translated into Chinese by the research team, and then discussed with some Chinese academic staff. Those academic staff were bilingual and also had many years of professional experience in the construction industry, especially in the construction management field. In particular, they were experienced in detecting misleading messages due to inappropriate translation. The Chinese version of the questionnaire was then revised based on their comments. Subsequently the Chinese version of the questionnaire was translated back into English to test that the meanings had not been altered.

Subsequently some twenty industry practitioners in China were invited to participate in pilot-testing of the questionnaire. Those practitioners had been involved in the local industry for at least ten years and accordingly they served as a good contextual benchmark against which to test the Chinese version of the questionnaire. Their feedback suggested that the content and the format of the questionnaire were appropriate for China. They also suggested that follow-up interviews should be conducted in order to find out more in-depth information on the cultural issues in construction projects and how this would affect the performance of these projects. They strongly recommended interviewing some officers of the relevant government departments. The Ministry of Construction and the respective Provisional / Municipal Committee of Construction were highlighted as the key government authorities in the local industry. They also suggested that a study based on Beijing and Shenzhen could be considered as a representative sample of the Chinese construction industry.

A five-point Likert Scale was used to examine the extent of correlation between perception of project participants about the culture and performance of construction projects (see Figure 1).

The Chinese construction industry uses a qualification and registration system for contractors in that contractors are ranked into four classes according to their contracting ability: 1) special class (highest rank); 2) first class; 3) second class; 4) third class. As the highest rank, the special class contractors are allowed to bid for mega and complex projects. The target population was the special class contractors in Beijing and Shenzhen. These two cities comprise developed areas with many large construction projects already built or under construction. The researchers believe that these two cities represent the situation at the forefront of current construction practice in China.

The contractors were approached for permission to distribute the questionnaire within their companies and ten agreed to participate in the research. A coordinator was appointed in each company to coordinate the survey process. The coordinators helped distribute the questionnaire to twenty randomly selected construction managers in their companies. After one month, the coordinator collected the completed questionnaires and forwarded them to the researchers.

One hundred and sixty-five construction managers from a majority of contractors answered the questionnaire. Of those returned, 158 questionnaires were able to be analysed. Others were either not answered completely or contained an unreliable pattern of answers (for example, all questions were answered with the same score). The response rate was 79 percent (158/200). 


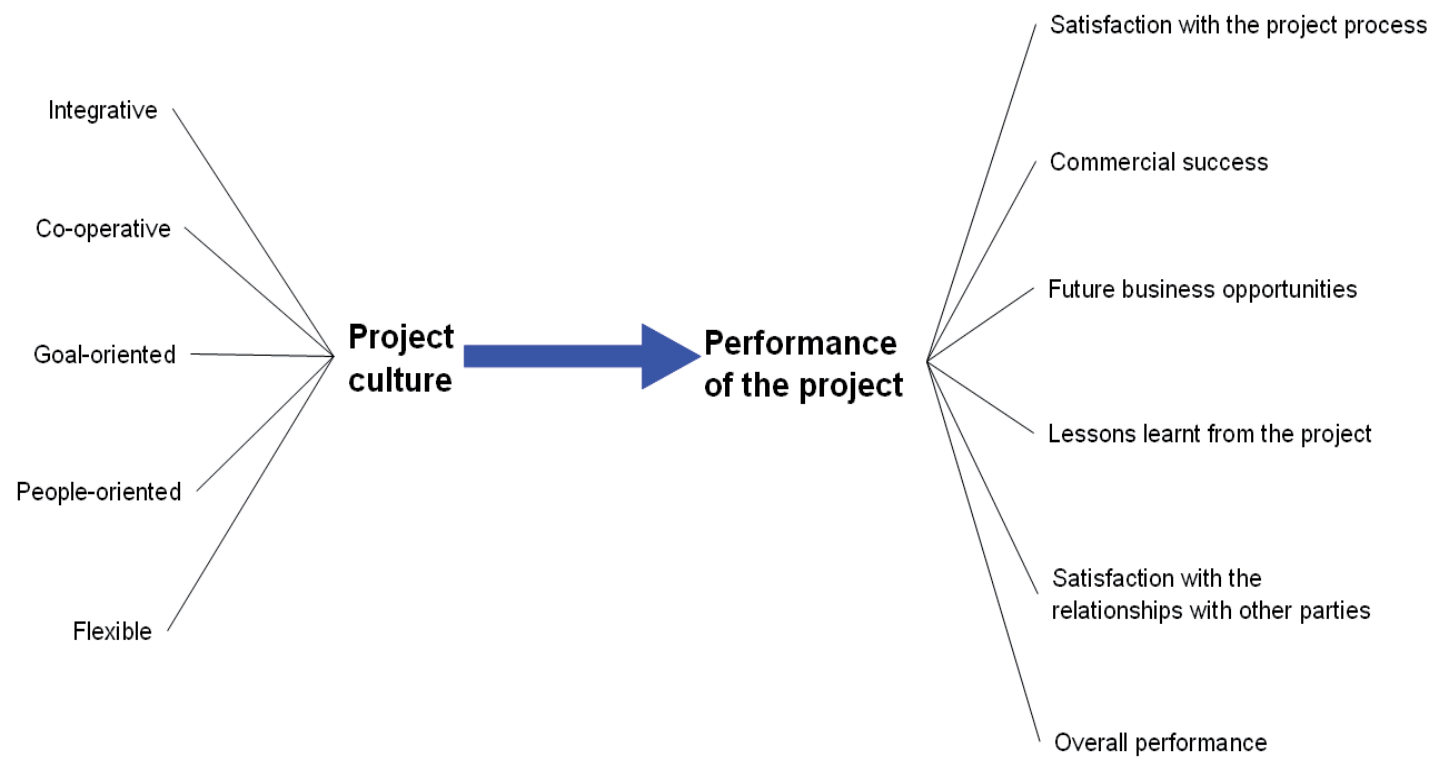

In addition to the above, a range of in-depth interviews were conducted to investigate:

- the manifestation of project culture in actual projects, and

- how project culture affects the performance of construction projects.

The interviewees were executive managers and senior construction managers of the major construction companies in Beijing and Shenzhen, China. They were approached for their comments about project culture issues and the impacts of these on the performance of construction projects. A total of 43 industry persons were interviewed, including 38 executive managers and senior construction managers and five government officers. They were selected because of: (1) their extensive experience in the local industry, (2) the positions they held, and (3) they were available at the time when the research was undertaken. All interviewees had more than 10 years professional experience in the local construction industry. Three quarters of the interviewees had worked in the industry for more than 16 years. It is also important to note that 32 out of the 43 interviewees (a significant majority) had worked on international projects. This enabled them to compare a variety of experiences in different construction projects regarding project culture and procurement approach issues.

During the pilot studies, the industry practitioners suggested that interviews should concentrate on senior management because: (1) it is more probable that these people have more knowledge of the cultural and procurement approach issues than junior managers and labourers, (2) they normally have more professional experience in the industry, and (3) people in senior positions make project and corporate decisions. Accordingly, contractor interviewees comprised executive managers or senior construction managers in major construction companies in China.

Government intervention in the Chinese construction industry is still comparatively high when compared to Western countries such as Australia. The researchers were fortunate to have the opportunity to interview government officials as this is rare in China. The officials were drawn from the Ministry of Construction, the Beijing Municipal Construction Committee and the Shenzhen Municipal Construction Committee. These government interviewees were in charge of the construction market at both the national and municipal level and were thus in an excellent position to supplement the comments made by the interviewees from the private sector. These government officers' comments were extremely useful about how the research findings could be implemented in China.

\section{HYPOTHESIS TESTING}

Sekaran (1992) defined a hypothesis as a logically conjectured relationship between two or more variables expressed in the form of testable statements. A hypothesis needs to be testable, positive and be expressed in clear and simple language (Fellows and Liu, 2002).

The hypothesis for this study is:

\section{H1: an Eastern style of approach is responsible for improved project performance.}

The null hypothesis is:

HO: an Eastern style of approach is not responsible for improved project performance.

As the literature survey found, an Eastern style of approach is seen as more integrative, more cooperative, more people-oriented, less goal-oriented and less flexible. Project performance is meaured by the perceptions of respondents by satisfaction with the process, commercial success, future business opportunities, lessons learnt from the project, satisfaction with the relationship, and overall performance.

\section{QUESTIONNAIRE FINDINGS}

\section{DESCRIPTIVE ANALYSIS}

Overall, $79 \%$ of respondents had more than ten years of professional experience in the construction industry, thereby 
making them well-qualified to answer the questionnaire and comment on the research questions, as shown in Figure 2.

As mentioned previously, all the contractors involved comprised major construction companies in terms of market share and were of the highest rank in the qualification and registration system for Chinese contractors. $90 \%$ of their projects exceeded RMB $\$ 50 \mathrm{~m}(\mathrm{AUD} \$ 8.33 \mathrm{~m}$ ) in value and 60 percent of all projects had a construction value of more than RMB $\$ 500 M$ (AUD\$83.33m), as shown in Figure 3.

\section{RELIABILITY ANALYSIS}

The internal consistency of the questions belonging to the five cultural dimensions was checked by means of Cronbach's alpha coefficients (Liu, 1999). Since the coefficients are all above the acceptable level of 0.70 (see Table 3 ), the reliability of the constructs was accepted for further analysis.

\section{PEARSON CORRELATION ANALYSIS}

The Pearson correlation coefficients were computed to determine whether the variables (dimensions of project culture and indicators of project performance) were statistically correlated (see Figure 4). These show that, among the five dimensions of project culture, only flexible and people-oriented types of project culture have a significant correlation with the lessons learnt from the project. These correlations are comparatively small however (around 0.3). There are also significant correlations between the rest of the performance indicators (i.e. satisfaction with the project process, commercial success, future business opportunities, satisfaction with the relationships with other parties, and overall performance).

There are medium to large positive correlations between all five dimensions of the project culture and all indicators of the performance of the project except lessons learnt from the project (see Figure 4). The strongest correlations (significant at the 0.01 level - 2 tailed) are:

- $\quad$ satisfaction with the project process - integrative culture

- commercial success - goal-oriented culture

- future business opportunities - integrative culture

- lessons learnt from the project - flexible culture

- $\quad$ satisfaction with the relationships with other parties integrative culture

- overall performance - integrative culture

The majority of these correlations are positive except that goaloriented and flexible culture has a negative correlation with the performance of the project in terms of: (1) satisfaction with the project process, (2) commercial success, (3) future business opportunities, (4) satisfaction with the relationships with other parties, and (5) overall performance. This suggests that strongly goal-oriented and flexible approaches should be avoided in order to achieve better project outcomes and that:

- $\quad$ project culture does contribute towards the better performance of construction projects, and

- the items in the questionnaire do identify those features of the project culture that lead to better project performance.

\section{MULTIPLE REGRESSION ANALYSIS}

Multiple regression analysis (MRA) was used to predict to what extent each project culture dimension contributed to each project performance variable. The regression models can be seen in Table 4. The MRA results are consistent with the correlation analysis results. As shown in the Table 4, five dimensions defined in the established project culture model explain at least 41.6 per cent of the variance in most of the project performance variables. This is considered to be satisfactory.

The only exception is the regression model for lessons learnt from the project. Table 4 indicated that only two project cultural dimensions (i.e. flexible and people-oriented culture) are correlated with this project performance variable. As shown in Table 4, five project culture dimensions explain 11.2 per cent of the variance of lessons learnt from the project.

Table 5 indicates that the integrative project culture dimension makes the strongest contribution to explaining most of the project performance variables. Therefore, in order to achieve exceptional performance, the project team should aim to develop and maintain an integrative culture. Furthermore, flexible and peopleoriented cultures are conducive to an integrative culture and not mutually exclusive.

Given all of the above, the hypothesis $(\mathrm{H} 1)$ is accepted $(p<0.05)$ $-i$.e. that an Eastern style of approach is responsible for improved project performance subject to some minor deviations in the lessons learnt variable. Therefore the following two subhypotheses will be accepted $(p<0.05)$ :

- $\quad \mathrm{H} 1.1$ : an Eastern style of approach is responsible for improved project performance that is measured by satisfaction with the project process, commercial success, future business opportunities, satisfaction with the relationships with other parties, and overall performance.

- H1.2: Flexible and people-oriented types of project culture are responsible for improved project performance, which is measured by lessons learnt from the project.

\section{INTERVIEW FINDINGS}

\section{THE CURRENT STATE OF PROJECT CULTURE ISSUES IN THE INDUSTRY}

The common theme expressed by interviewees is that a confrontational culture exists within a typical construction project. Of the various reasons given for this is that it is not unusual for the client to dominate during the life-cycle of the project, thereby making it more difficult for contractors to be involved in the decision-making process. One interviewee showed his disappointment by stating:

\section{"...From my point of view, as the contractor, I feel that our construction capabilities could help to improve the constructability of the project. But we seldom have the chance to do so. We are left out of the door of the decision making room - quite disappointing."}

This is an interesting response as the conventional wisdom in Western (or outside Chinese) construction organisations is that early involvement of the builder is an important benefit to a project and procurement systems often try to achieve that outcome through partnering or other relationship management techniques between designer, client and builder. 

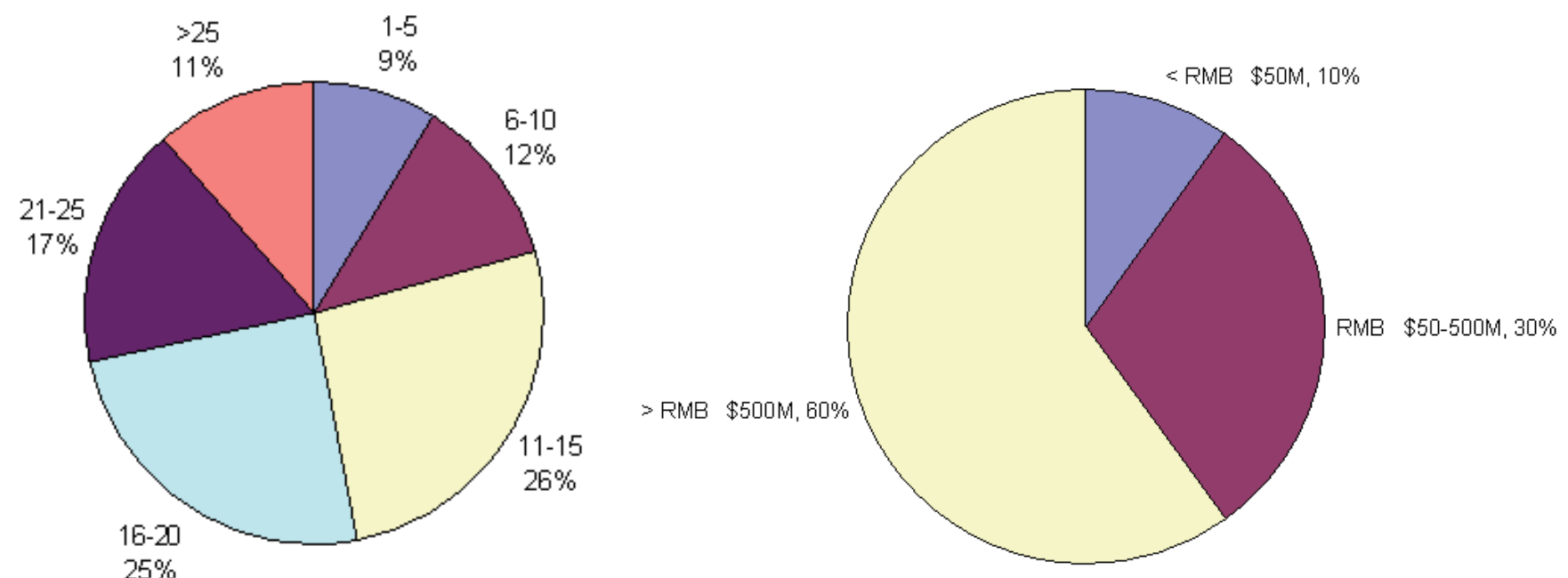

Figure 4: Perceived statistical relationships between project culture and project performance

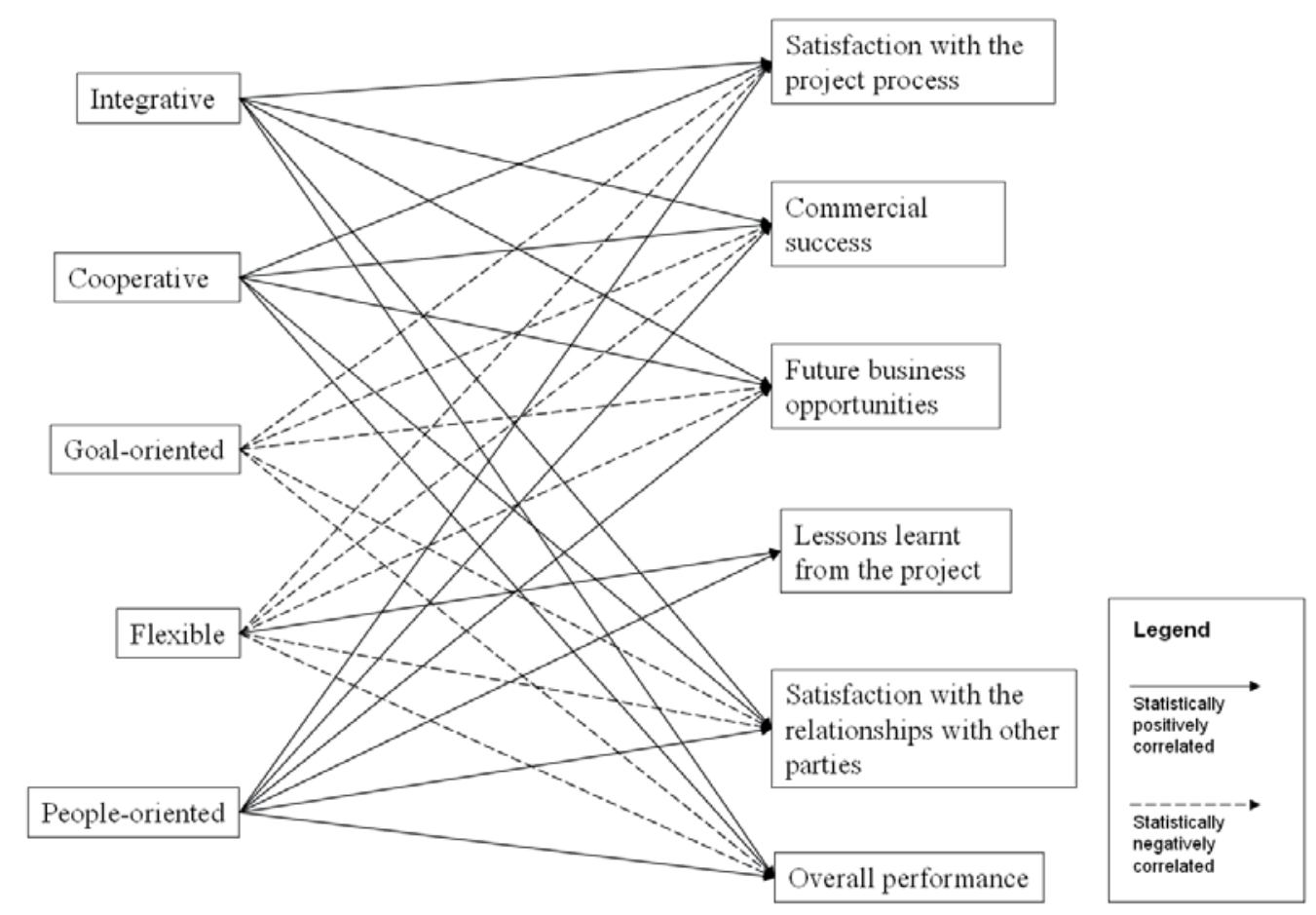

Table 3: Reliability of internal consistency

\begin{tabular}{lcc}
\hline Dimensions of the project culture & Number of questions & $\begin{array}{c}\text { Cronbach's alpha } \\
\text { coefficient }\end{array}$ \\
\hline Integrative & 10 & 0.886 \\
Cooperative & 8 & 0.802 \\
Goal-oriented & 5 & 0.766 \\
Flexible & 6 & 0.773 \\
People-oriented & 6 & 0.899 \\
\hline
\end{tabular}


Table 4: Multiple regression models

\begin{tabular}{llr}
\hline Model & $\mathrm{R}$ & R Square \\
\hline Satisfaction with the process & .721 & .520 \\
\hline Commercial success & .645 & .416 \\
\hline Future business opportunities & .689 & .474 \\
\hline Lessons learnt from the project & .334 & .112 \\
\hline Satisfaction with the relationship & .727 & .529 \\
\hline Overall performance & .725 & .526 \\
\hline
\end{tabular}

Table 5: Reliability of internal consistency

\begin{tabular}{|c|c|c|c|c|c|c|}
\hline \multirow[b]{2}{*}{ Model } & \multicolumn{6}{|c|}{ Standardized Coefficients (Beta) } \\
\hline & $\begin{array}{r}\text { Satisfaction with } \\
\text { the process }\end{array}$ & $\begin{array}{r}\text { Commercial } \\
\text { success }\end{array}$ & $\begin{array}{r}\text { Future business } \\
\text { opportunities }\end{array}$ & $\begin{array}{l}\text { Lessons learnt } \\
\text { from the project }\end{array}$ & $\begin{array}{l}\text { Satisfaction with } \\
\text { the relationship }\end{array}$ & $\begin{array}{r}\text { Overall } \\
\text { performance }\end{array}$ \\
\hline Integrative & $.617^{\star *}$ & $.541^{\star *}$ & $.572^{* *}$ & .176 & $.628^{* *}$ & $.652^{\star \star}$ \\
\hline Cooperative & $.589^{\star \star}$ & $.485^{\star \star}$ & $.527^{\star \star}$ & .127 & $.593^{\star \star}$ & $.591^{* *}$ \\
\hline Goal-oriented & $-.469^{\star \star}$ & $-.587^{\star \star}$ & $-.526^{\star \star}$ & -.094 & $-.498^{\star \star}$ & $-.487^{\star \star}$ \\
\hline Flexible & $-.574^{\star \star}$ & $-.412^{\star \star}$ & $-.482^{* *}$ & $.261^{* *}$ & $-.615^{\star \star}$ & $-.485^{\star \star}$ \\
\hline People-oriented & $.590^{\star \star}$ & $.435^{\star \star}$ & $.511^{\star \star}$ & $.235^{\star}$ & $.602^{\star \star}$ & $.512^{\star *}$ \\
\hline
\end{tabular}

\section{COMMON FEATURES OF APPROPRIATE PROJECT CULTURE}

All interviewees agreed that specific features of project culture helped to foster a collaborative relationship among project participants and in turn achieved optimum project outcomes, as shown in Figure 5.

\section{THE CLIENT"S NEEDS}

To satisfy the clients' needs is identified as the major function of project culture. According to the interviewees, no matter what the culture is in the project, if it does not fit the client's requirements, it is not a good culture.

There are generally two types of requirements from the client's perspective, namely explicit requirements and implicit requirements. For the interviewees, the implicit requirements (the subjective measures) rather than the explicit requirements (objective measures) were more important.

One interviewee went on to explain that the subjective measures important to him were good relationships, especially personal relationships with the rest of the project team (and with the client and/or the client representative in particular). Guanxi (关系) is important for achieving business success in Confucian societies such as China (Yeung and Tung, 1996; Buttery and Wong, 1999).

\section{GOOD RELATIONSHIPS, WILLINGNESS TO HELP AND TEAMWORK}

Good relationships, especially interpersonal relationships, were identified as key characteristics of an appropriate project culture. The owner, the designer, the main contractor and subcontractors were identified as the most important stakeholders. For instance, one interviewee stated: "Good relationships means that each party would like to consider the other parties' interests and objectives. The Chinese call it 'thinking by standing in the other's position'. Certainly the clients' needs are the ultimate consideration and should be the common goal of all participating parties."

\section{EQUAL POSITION OF ALL PARTIES}

One theme that featured in the interviews was the need for all contracting parties to be equal. Being located at the bottom of the supply chain, subcontractors are vulnerable to being treated unfairly and there were many occasions when subcontractors could not secure their scheduled payments.

\section{COMMON INTERESTS / VALUES / GOALS AND CONSIDERATION OF OTHERS}

The majority of interviewees stressed the importance of the whole project team having a common goal. According to them, a mismatch of objectives of the participating parties in a construction project is detrimental to both inter-firm relationships and the performance of the project. According to the interviewees, all participants should have a common goal - the project objectives - rather than focusing on their own interests.

\section{EFFECTIVE COMMUNICATION}

Another feature that was identified as part of an appropriate project culture was effective communication among participants. Poor communication can frustrate team members and create a tense atmosphere. From the beginning of the project, each party's responsibility, power and benefits should be stated very clearly. In many cases, conflicts emerge simply because there is a lack of such communication. 


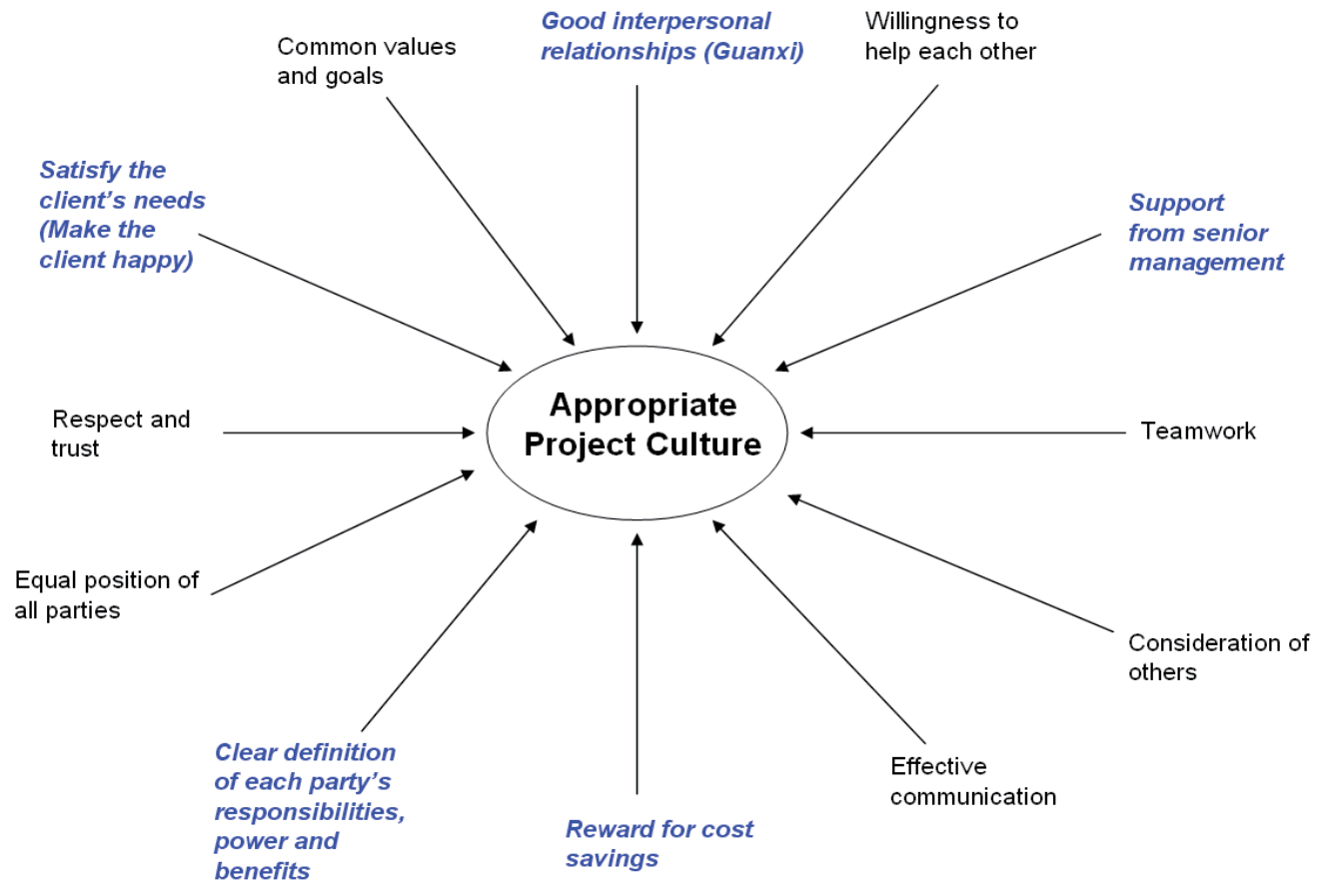

\section{ECONOMIC BENEFITS}

Rewarding cost savings was highlighted by interviewees as an important feature of an appropriate project culture. From the interviewee's point of view, the cooperation and willingness to help each other should not be based upon money lost. For instance, if the cost savings derived from an initiative are not enough to cover the cost of the commitment, there will not be many companies prepared to make efforts to build an appropriate project culture.

\section{RESPECT AND TRUST}

Trust is another feature identified as part of an appropriate project culture. Lacking common goals, the achievement of one party's objectives might be based on sacrificing another party's interests. One interviewee noted that, in order to win the contract, the contractor might submit a bid with little or no profit margin, or even below cost, in the expectation that he will be able to put in later claims that will make the work profitable. This deliberate approach leads to distrust between the contracting parties.

\section{SUPPORT FROM SENIOR MANAGEMENT}

Interviewees commented that support from senior management is one aspect of appropriate project culture. With no support from senior management, it is very hard to develop and maintain a positive project culture throughout the project lifecycle.

\section{IMPORTANCE OF THE PROJECT CULTURE}

All interviewees acknowledged the importance of project culture, especially its impacts on the performance of construction projects. It is interesting to note, however, that most construction manager interviewees highlighted the difficulties in establishing an appropriate project culture, even though they acknowledged the crucial role that this played. Eighteen contractor interviewees were concerned about the affordability of developing a project culture (i.e. resources required). Senior managers, however, had different views - stressing that it was still necessary to develop and sustain an appropriate culture. As one interviewee stated:

"There is no doubt that the project culture plays a key role in improving the performance of construction projects. Certain resources, for example, time and cost, are required to develop an appropriate project culture from very early on. The Chinese know this as "sharpening the axe means that you don't waste time when you are chopping wood".

\section{FLEXIBLE AND GOAL-ORIENTED CULTURE}

Interviewees were asked to make comments, particularly on the findings from the questionnaire survey, and these indicated that flexible and goal-oriented project cultures should be avoided so that a better project outcome can be achieved. These two features of project culture have a positive correlation with the performance of construction projects (Anderson, 2003; Zuo and Zillante, 2006b; Olsson, 2006).

Interestingly, interviewees emphasised that they recognised the benefits of being flexible and goal-oriented. However, these need to be considered carefully in the Chinese context. They explained that in order to run a project smoothly, it is not enough to focus on the result whilst ignoring the process. All interviewees believed that it is hard to achieve the project objective (outcome) if there are no well-defined procedures or rules.

In addition, interviewees expressed concerns about the uncertainties existing in the project. There was a consensus view that every effort should be made to minimise the uncertainties. Furthermore, it was perceived by interviewees that Chinese project managers are generally reluctant to take risks. Failure is not viewed as an opportunity for learning and improvement.

\section{DISCUSSION AND IMPLICATIONS}

Both the questionnaire survey and the in-depth interviews serve to identify features of project culture that lead to better project 
performance. The results indicate that certain types of project culture do contribute towards better project performance.

The statistical analysis of the questionnaire responses indicated that integrated, cooperative and people-oriented cultures should be developed so as to achieve better project outcomes.

Naoum (2003) noted that one of the features of the construction industry is its fragmented nature, in that design is separated from construction. In construction, integration helps to: (1) create a culture of efficient and effective collaboration by individuals and organisations, (2) promote a working environment where information is freely exchanged between different participants, and (3) improve the effective and efficient delivery of the project (Baiden et al., 2006).

Cooperation, characterised by mutual trust, teamwork, open communication and exchange of information, openness and honesty is identified as one of most important factors for the success of construction projects (Walker et al., 2002). According to the Australian Procurement and Construction Council (APCC) developing capabilities of employees is crucial if one wishes to improve the competitiveness and effectiveness of the Australian construction industry (APCC, 1997).

Chinese culture focuses on maintaining harmony and building trust among people (Batonda and Perry, 2003). 'Face' is very important for the Chinese people and face-saving behaviour ensures harmony within the group. Wherever possible, efforts should be made to save the face of oneself and others. It is embarrassing if face is challenged in public. Face will be lost when the person (or those related to him) fails to meet essential requirements placed upon him by virtue of his social position. This includes the loss of reputation or standing in the eyes of others (Frank et al., 2000). It is essential for the Chinese to avoid confrontation and preserve any vertical authority relationship. Coupled with the high power distance of Chinese culture (Hofstede, 2001), it is very hard for Chinese practitioners to 'talk straight', which is identified in Western cultures as a key feature of positive project culture (Zuo et al., 2006).

The survey findings also showed that the outcome-oriented and flexible types of project culture had a significant negative correlation with the performance of construction projects. This indicates that Chinese practitioners focus not only on project outcomes but also on the process of the project that achieved those results. In addition, Chinese practitioners tend to be risk averse and uncomfortable with uncertain situations and prefer a stable project environment (stable rather than flexible).

Hofstede (2001) pointed out that a process-oriented culture is dominated by technical and bureaucratic routines. The main characteristics of a process-oriented culture include: cohesiveness, openness and generosity, preparedness and involvement and creativity (Huse et al., 2005), indicating that a process-oriented culture is crucial for contributing to the decision making process.

The interview results indicated that Chinese practitioners would like to pay more attention to building and maintaining interpersonal relationships with other project team members. Interpersonal relationships are often referred to as Guan Xi, (or guanxi) which is defined as 'a relationship combined with reciprocity of special relationships that two persons have with each other' (Kwan and Ofori, 2001). Guanxi connections are the preferred informational networks for the Chinese and may facilitate transactions (Martinsons and Westwood, 1997). Guanxi among key project stakeholders is already known to be one of most important criterion of project success in China (Wang and Huang, 2006) - its development also being said to be a key strategy for a foreign architectural design and construction firm to do business in China (Zou and Wang, 2007).

Collectivism and high uncertainty avoidance are also two features of Chinese culture (Fan, 2000; Brockner et al., 2001; Zhao and $\mathrm{Hu}, 2003)$. From a national culture perspective, a high uncertainty avoidance ranking indicates the country has a low tolerance for uncertainty and ambiguity (Hofstede, 2001). Uncertainty avoidance (UA) affects practitioners' attitudes to risk and approaches to the management of risk. A strong UA culture of Chinese practitioners indicates that they are uncomfortable with uncertain or unstructured situations, and prefer predictability and stability. They tend to fear unfamiliarity and risky or ambiguous situations. Risk avoidance and risk aversion are the usual actions taken in such circumstances (Chen and Partington, 2004). There is a sharp difference in behaviour among organisational members towards people from other organisations which results in greater hostility towards those who do not belong to one's own organisation (Phua, 2002; Phua and Rowlinson, 2003). Perceptions of the in-group versus the out-group among project participants that largely come from a collectivist society could have a significant effect on group members' attitudes towards each other as well as on their willingness to cooperate in the construction project environment (Phua and Rowlinson, 2004). This again indicates that Chinese practitioners prefer stable rather than flexible project environments.

From the interviewees' perspective it is clear that for the success of the project, the relationship with the client is more important than the relationship with the rest of the team. This is particularly important for Chinese construction projects, where the client has absolute power to make the decision of whether or not to award a contract, to appoint or dismiss a project manager (and consequently his long-term team) and to decide when and how much to pay for the work (Chen and Partington, 2004).

Western project management practice will not necessarily be supported by Chinese culture (Chen and Partington, 2004). There are three traits of Chinese traditional culture that are major cultural barriers to the adoption of western project management in Chinese enterprises. These comprise strong hierarchy, family consciousness, and boss orientation (Wang and Liu, 2007). This suggests that industry practitioners from western countries would benefit significantly by having a better understanding of Chinese culture when entering the Chinese construction market.

\section{CONCLUSION}

The questionnaire survey of the construction managers from the major construction companies revealed that statistically there is strong correlation between the project culture and the project outcomes from the Chinese industry practitioners' perspective. It is interesting to note that goal-orientation and flexibility, as two dimensions of the project culture, have a (statistically) significant negative correlation with perceived performance of construction projects in terms of the satisfaction with the process, commercial success, future business opportunities, lessons learnt from the project, satisfaction with the relationships of other parties, and overall performance. It is clear that Chinese practitioners focus on the process of the project as well as the outcomes.

All those who took part in the in-depth interviews agreed that project culture has a significant effect on project performance. They acknowledged that a positive and appropriate culture does 
contribute towards the success of construction projects. However, the findings also showed that the affordability of developing an appropriate project culture is a major concern of industry practitioners. The results indicate that respondents associate classical Eastern culture characteristics with improved project performance in China.

One limitation of this study is that six subjective indicators were adopted to measure the performance of construction projects. The incorporation of objective measures (e.g. key performance indicators) will help to validate the performance evaluation. Similarly, this research only covered two developed cities, i.e. Beijing and Shenzhen. A wider survey from more areas will be helpful to further validate the findings. In addition, it would be beneficial to have more in-depth interviews of parties other than contractors to further establish the nature of culture at the project level and its impacts on the project outcomes.

\section{ACKNOWLEDGEMENTS}

The authors would like to acknowledge the contributions from the industry professionals by attending the interviews and answering the questionnaire. For reasons of confidentiality their names cannot be listed. Similarly, the authors acknowledge the contribution of Professor Martin Skitmore for his constructive suggestions on how to improve this paper.

\section{REFERENCES}

Anderson, E.S. (2003) ‘Understanding your project orgnization's character', Project Management Journal, 34(4), 4-11.

APCC (1997) Construct Australia: Building a better construction industry in Australia, Australian Procurement and Construction Council (available from http://www.apcc.gov.au/docs/construct australia.pdf).

Arditi, D., Elhassan, A. and Toklu, Y.C. (2002) 'Constructability analysis in the design firm', Journal of Construction Engineering and Management, 128(2), 117-126.

Baiden, B.K., Price, A.D.F. and Dainty, A.R.J. (2006) 'The extent of team integration within construction projects', International Journal of Project Management, 24(1), 13-23.

Baloi, D. and Price, A.D.F. (2003) 'Modelling global risk factors affecting construction cost performance', International Journal of Project Management, 21(4), 261-269.

Bassioni, H.A., Price, A.D.F. and Hassan, T.M. (2005) ‘Building a conceptual framework for measuring business performance in construction: an empirical evaluation', Construction Management and Economics, 23(5), 495-507.

Batonda, G. and Perry, C. (2003) 'Influence of culture on relationship development processes in overseas Chinese/ Australian networks', European Journal of Marketing, 37(11/12), 1548-1574.

Black, C., Akintoye, A., Fitzgerald, E. (2000) 'An analysis of success factors and benefits of partnering in construction', International Journal of Project Management, 18(6), 423-434.
Brockner, J., Ackerman, G., Greenberg, J., Gelfand, M.J., Francesco, A.M., Chen, Z.X., Leung, K., Bierbrauer, G., Gomez, C., Kirkman, B.L. and Shapiro, D. (2001) 'Culture and procedural justice: the influence of power distance on reactions to voice', Journal of Experimental Social Psychology, 37(4), 300-315.

Buttery, E.A. and Wong, Y.H. (1999), 'The development of a Guanxi framework', Marketing Intelligence and Planning, 17(3), 147-155.

Cameron, K. and Quinn, R.E. (1999), Diagnosing and changing organizational culture: based on the competing values framework, Addison Wesley.

Chan, A.P.C. and Chan, A.P.L. (2004) 'Key performance indicators for measuring construction success', Benchmarking: An International Journal, 11(2), 203-221.

Chan, E.H.W. and Tse, R.Y.C. (2003) 'Cultural considerations in international construction contracts', Journal of Construction Engineering and Management, 129(4), 375-381.

Chen, P. and Partington, D. (2004) 'An interpretive comparison of Chinese and Western conceptions of relationships in construction project management work', International Journal of Project Management, 22(5), 397-406.

Cox, R.F., Issa, R.R.A. and Ahrens, D. (2003) 'Management's perception of key performance indicators for construction', Journal of Construction Engineering and Management, 129(2), 142-151.

Diallo, A. and Thuillier, D. (2004), 'The success dimensions of international development projects: the perceptions of African project coordinators', International Journal of Project Management, 22(1), 19-31.

Fan, Y. (2000) 'A classification of Chinese culture', Cross Cultural Management: An International Journal, 7(2), 3-10.

Fellows, R. and Liu, A. (2002) Research methods for construction (2nd edition), Blackwell Science.

Frank, H., Harvey, O. and Verdun, K. (2000) 'American responses to five categories of shame in Chinese culture: a preliminary cross-cultural construct validation', Personality and Individual Differences, 28, 887-896.

Gareis, R. and Huemann, M. (2000) 'Project management competences in the project-based organization', in Turner J.R. Simister S.J. and Lock, D. (eds), The Gower Handbook of Project Management (3rd edition), Aldershot: Gower.

Gray, C.F. and Larson, E.W. (2000) Project management: the managerial process, Irwin McGraw-Hill.

Gray, R.J. (2001) 'Organisational climate and project success', International Journal of Project Management, 19(2), 103-109.

Handy, C.B. (1985) Understanding organizations (3rd edition), Penguin.

Harrison, R. (1972) 'Understanding your organization's character, Harvard Business Review, 50(3), 119. 
Hofstede, G. (2001) Culture's consequences: comparing values, behaviors, institutions, and organizations across nations (2nd edition), Sage Publications.

Huse, M., Minichilli, A., Schøning, M. (2005) 'Corporate boards as assets in the new Europe: the value of process-oriented boardroom dynamics', Organizational Dynamics, 34, 285-297.

Kog, Y.C., Chua, D.K.H., Loh, P.K. and Jaselskis, E.J. (1999) 'Key determinants for construction schedule performance', International Journal of Project Management, 17(6), 351-359.

Korzilius, L.P. (1988) A system and contingency analysis applied to construction projects of exceptional architectural design (available from http://www.lesterkorzilius.com/pubs/msc/MSC-0. $\mathrm{htm})$.

Kumaraswamy, M.M., Rowlinson, S.M. and Phua, F.T.T. (2001) 'Origins and desired destinations of construction project cultures', in proceedings of CIB TG-23 Workshop on Culture in Construction, CIB World Congress, Wellington, New Zealand.

Kumaraswamy, M., Rowlinson, S., Rahman, M. and Phua, F. (2002) 'Strategies for triggering the required 'Cultural Revolution' in the construction industry', in Fellows, R.F. and Seymour, D.E. (eds), Perspectives on culture in construction, CIB Publication no. $275,268-285$.

Kwan, A.Y. and Ofori, G. (2001) 'Chinese culture and successful implementation of partnering in Singapore's construction industry', Construction Management and Economics, 19(6), 619632.

Lam, E.W.M., Chan, A.P.C. and Chan, D.W.M. (2007) 'Benchmarking the performance of design-build projects: development of project success index', Benchmarking: An International Journal, 14(5), 624-638.

Lim, C.S. and Mohamed, M.Z. (1999) 'Criteria of project success: an exploratory re-examination', International Journal of Project Management, 17(4), 243-248.

Liu, A.M.M. (1999) Culture in the Hong Kong real-estate profession: a trait approach', Habitat International, 23(3), 413425.

Loosemore, M. and MusImani, H.A. (1999) 'Construction project management in the Persian Gulf: inter-cultural communication', International Journal of Project Management,17(2), 95-100.

Low, S.P. and Shi, Y. (2002) 'An exploratory study of Hofstede's cross-cultural dimensions in construction projects', Management Decision, 40(1/2), 7-16.

Luu, T.V., Kim, S.Y., Cao, H.L. and Park, Y.M. (2008)

'Performance measurement of construction firms in developing countries', Construction Management and Economics, 26(4), 373386.

Martinsons, M.G. and Westwood, R.I. (1997) 'Management information systems in the Chinese business culture: an explanatory theory', Information and Management, 32(5), 215228.

McGeorge, W.D., Palmer, A., London, K. (2002) Construction management: new directions (2nd edition), Blackwell Science.
Naoum, S. (2003) 'An overview into the concept of partnering', International Journal of Project Management, 21(1), 71-77.

Odusami, K.T., lyagba, R.R.O. and Omirin, M.M. (2003) 'The relationship between project leadership, team composition and construction project performance in Nigeria', International Journal of Project Management, 21(7), 519-527.

Olsson, N. (2006) 'Management of flexibility in projects', International Journal of Project Management, 24(1), 66-74.

Phua, F.T.T. (2002) 'Effects of cultural differences on project participants' co-operative behaviour in construction projects', in proceedings of Procurement Systems and Technology Transfer, CIB W92 Procurement Systems Symposium, St Augustine, Trinidad and Tobago.

Phua, F.T.T. and Rowlinson, S. (2003) 'Cultural differences as an explanatory variable for adversarial attitudes in the construction industry: the case of Hong Kong', Construction Management and Economics, 21(7), 777-785.

Phua, F.T.T. and Rowlinson, S. (2004) 'Operationalizing culture in construction management research: a social identity perspective in the Hong Kong context', Construction Management and Economics, 22(9), 913-925.

Rowlinson, S. (2001) 'Matrix organizational structure, culture and commitment: a Hong Kong public sector case study of change', Construction Management and Economics, 19(7), 669-673.

Sawacha, E., Naoum, S. and Fong, D. (1999) 'Factors affecting safety performance on construction sites', International Journal of Project Management, 17(5), 309-315.

Sekaran, U. (1992) Research methods for business: a skillbuilding approach (2nd edition), Wiley.

Shenhar, A.J., Dvir, D., Levy, O. and Maltz, A.C. (2001) 'Project success: a multidimensional strategic concept', Long Range Planning, 34(6), 699-725.

Sözen, Z. and Kayahan, O. (2001) 'Correlates of the length of the relationship between main and specialist trade contractors in the construction industry', Construction Management and Economics, 19(2), 131-133.

Thomas, R., Marosszeky, M., Karim, K., Davis, S. and McGeorge, D. (2002) 'The importance of project culture in achieving quality outcomes in construction', in proceedings of 10th Annual Conference of the International Group of Lean Construction, 6-8 August, Gramado, Brazil.

van Marrewijk, A. (2007) 'Managing project culture: the case of Environ Megaproject', International Journal of Project Management, 25(3), 290-299.

Walker, A. (2002) Project management in construction (4th edition), Blackwell Science.

Walker, D.H.T., Hampson, K. and Peters, R. (2002) ‘Project alliancing vs project partnering: a case study of the Australian National Museum Project', Supply Chain Management: An International Journal, 7(2), 83-91.

Wang, X. (2001) 'Dimensions and current status of project management culture', Project Management Journal, 32(4), 4-19. 
Wang, X. and Huang, J. (2006) 'The relationships between key stakeholders' project performance and project success: perceptions of Chinese construction supervising engineers', International Journal of Project Management, 24(3), 253-260.

Wang, X. and Liu, L. (2007) 'Cultural barriers to the use of Western project management in Chinese enterprises: some empirical evidence from Yunnan province', Project Management Journal, 38(3), 61-73.

Westerveld, E. (2003) 'The Project Excellence Model@: linking success criteria and critical success factors', International Journal of Project Management, 21(6), 411-418.

Whyte, J., Bouchlaghem, D. and Thorpe, T. (2002) 'IT implementation in the construction organization', Engineering Construction and Architectural Management, 9(5/6), 371-377.

Widmen, M. (2004) Wideman Comparative Glossary of Project Management Terms v3.1 (available from http://www. maxwideman.com/pmglossary/PMG_P11.htm).

Xiao, H. and Proverbs, D. (2002) 'The performance of contractors is Japan, the UK and the USA: An evaluation of construction quality', International Journal of Quality and Reliability Management, 19(6), 672-687.

Yeung, I.Y.M. and Tung, R.L. (1996) 'Achieving business success in Confucian societies: the importance of Guanxi', Organizational Dynamics, 25(2), 54-65.

Zhao, H. and Hu, X. (2003) Cultural adaptation on the Web: a study of American companies' domestic and Chinese websites', Journal of Global Information Management, 11(3), 63-80.

Zou, P.X.W. and Wong, A. (2007) 'Opportunities, risks and strategies for foreign architectural design and construction firms doing business In China', in proceedings of the 12th International Research Symposium on the Advancement of Construction Management and Real Estate, 8-13 August, Coogee Beach, Sydney, Australia.

Zuo, J. and Zillante, G. (2005), 'Project culture within construction projects: a literature review', in proceedings of the 13th Annual Conference of the International Group of Lean Construction, 1921 July, Coogee Beach, Sydney, Australia.

Zuo, J. and Zillante, G. (2006a) 'Project culture: the X factor for achieving optimum performance in construction projects?', Construction Information Quarterly, 8(4), 173-177.

Zuo, J. and Zillante, G. (2006b) 'Project culture within construction projects: a pilot case study', The International Journal of Construction Management, 6(2), 15-29.

Zuo, J., Ness, D. and Zillante, G. (2006) 'The Client's role in driving an appropriate project culture leading to innovative performance outcomes: a context of Australia and China', in Clients driving construction innovation: moving ideas into practice, K. Brown, K. Hampson and P. Brandon (eds), CRC for Construction Innovation, Brisbane, Australia. 